\title{
School Allowance and Students' Determination in Studies
}

\author{
Dr. Jerald C. Moneva \\ Department of Education, Mandaue City Division, Cebu, Philippines \\ E-mail: monevajerald5@gmail.com
}

Dr. Rey C. Miralles

Department of Education, Mandaue City Division, Cebu, Philippines

E-mail: merallesray@yahoo.com

Jonathan Raman

Jagobiao National High School, North Road, Jagobiao Mandaue City, Philippines

E-mail: jlintao88@gmail.com

Received: January 20, 2020 Accepted: February 11, 2020 Published: March 26, 2020

doi:10.5296/ber.v10i1.16751 URL: https://doi.org/10.5296/ber.v10i1.16751

\begin{abstract}
The study assessed the association of school allowance and students' determination in studies. The study used quantitative approach - the descriptive survey. The study was conducted in Jagobiao National High School - Senior High School Department. Mainly the Senior High School students are the respondents. The first part of the questionnaire talks about how students determines toward their studies. The weighted mean used to show how school allowance affects the determination of the students towards their studies. Using chi-square, it revealed that there was no significant association between school allowance and students' determination in studies. Students' determination in studies did not affect whether the school allowance of the students either high or low. In addition, students were determined in their studies sometimes. The students who were having a high socioeconomic status or low socioeconomic status did not affect their performance in school. In addition students' willingness in school was the factor why students are eager in their studies in school. Consecutively, to improve their determination in school they need to be interested in school
\end{abstract}


and participated in school activities.

Keywords: School allowance, Determination, Socioeconomic status, Finance, Academic performance, Exposure

\section{Introduction}

\subsection{Rationale}

School allowance refers to finance for students when they are in school. Allowance has a significant role when students buy their requirements for a particular subject. Allowance of the students may determine their interest on studies. It is interesting to know if students may determine if they have enough allowance. Parents provide allowance for students. It is very important to know whether socioeconomic status affects the performance and the determination of the students.

Character of the students towards their studies may determine their future success. Higher family income may improve students' performance. Nevertheless, it is not and indicator for students who are from low-income families not to get serious and be responsible in performing in school (Adzido, Dzogbede, Ahiave, and Dorkpah (2016). Students having a high socioeconomic status have a good exposure and surroundings giving a good result as compared to low socio economic status (Chandra and Azzimudin, 2013)

The status of a student in the society sees family income as a factor to consider regarding socioeconomic status (Okioga, 2013). Students now can be more attentive when it already had the need of improving their academic performance. Socioeconomic status of the students can be a factor when achieving and enhancing ones academic performance. School allowance plays a big role in daily school adventure. There can be an impact if the students allowance on school is not enough for them to focus when studying.

Students nowadays have money that can afford not just all but some of the requirements in school. Their allowance is already set by the things they want to spend. The academic performance of the students is increasing because of their allowance but some of the students who cannot even afford the requirements are also having the ability of improving their academic performance.

This study aims to know if there is significant relationship between socioeconomic status and the academic performance as well as the determination of Senior High School students of Jagobioa National High SchoolTable 1. The capitals, assets and revenue in listed banks

\subsection{Statement of Purpose}

The study intends to determine the relationship between school allowance and students determination in studies.

Specifically, the study seeks to answer the following sub problems:

1) What is the range of the students' daily allowance?

2) To what extent do students exert determination in their studies? 
3) Is there an association between school allowance and students determination in study.

Hypothesis:

Null: There is no association between school allowance and students determination.

Alternative: There is an association between school allowance and students determination in study.

\subsection{Significance of the Study}

The result of the study would benefit the following people:

Students will benefit knowledge on school allowance and how it be managed. It will give the students wisdom that school allowance can be a factor why students are determined to their studies.

Teachers will understand their students about their behavior in school or determination towards their study. The teachers would be able to understand on why students sometimes determined to their studies.

Parents will adjust the allowance that they give to their son/daughter. In addition, the given data will give knowledge to then on what is the significance of school allowance in line with the determination of the students.

School head will understand their students' action within the school and the performance shown to their respective classes. They will also understand their students why they have poor performance in school.

Community will benefit information in order to them to know the essence of school allowance to the students' life. They also benefit a knowledge about how to determination improve and how to manage a school allowance or finance.

Researcher will benefit an idea in order to have a good performance in school, they will have knowledge about self-determination and managing school allowance. The gathered data also give an understanding about the importance of finance in school towards the students' determination.

Future researcher will benefit in this study in terms of using this as a guide in identifying students' determination in study. Future researchers also use this as a reference material to their upcoming researches.

\subsection{Definition of Terms}

School allowance the following terminology is operationally defined to fully understand the study:

Students' determination in study is an attitude of a student that refers to the firmness in different things. It is also showing that students are already deciding to do something and they will not let anyone stop them. 
School allowance is a daily finance of the students that can help them to sustain their needs in school.

Socioeconomic Status usually categorized into three levels the high, middle, and low and these describes the places a family or an individual may fall into. Socioeconomic status is also measures a person's job experience, income, and occupation.

\section{Literature Review}

This study is supported by the different articles from the variables school allowance and students determination in studies.

Research studies revealed that teachers has a responsibility in the student's academic life (Alshammari, Saguban, Pasay-an, Alteban, \& Alshammari, 2017). It also exposed that even though there are students who are in full-time jobs, there are no effects on academic performance of students in school (Rossi, 2017). Financial status, parent's educational level, and attendance are the few different elements that influence the scholarly activity of the students (Jayanthi, Balakrishnan, Lim Siok Ching, AbdullLatiff \& Nasirundeen, 2014). In order to take initiatives in academic performance of students need to include efforts and make their selves aware academically for them to develop their academic performance (Shanzadi \& Ahmad, 2011). Students are mostly doing recapitulation the tackled lesson by memorizing the word again by themselves and this may become one of the styles of learning of the students (Gbolle \& Keamu, 2017). In addition, well-furnished study room with loaded equipment has a helpful outcome on the scores of the students. In that way, teachers can provide information to the students because they can now focus their attention to the lesson taught to them (Suleman \& Hussain, 2014). The proper utilizing of e-learning could help students increase their eagerness to go to school and improve their engagement in school activities especially their beliefs that they can benefit from their experiences and own efforts because correct answers are not only the basis for competence (Hardre, Sullivan \& Crowson, 2009).

Persistence could be an advanced development that lends students to achieve the specific online course (Hart, 2012). A study implied that both attitude and self-efficacy have strong effect on academic achievement (Li, 2012). Students' performance can be influenced by how they are been guided by their teachers and parents considering the learning facilities (Singh, Malik, \& Singh, 2016). Risk takers with a brave mind to nurture new things and develop their self-reliance are the classification of determined people. Collaboration with classmates with the help of the teacher-in-charge and a helping hand with each other will definitely eager to achieve high marks and various rewards (Saeed \& Zyngier, 2012). Students; academic achievement is greatly be influenced by what structure of a home or a family they have been raised (MeenuDev, 2016). In addition, researches tell that the rules and regulation of a school is responsibly important in enhancing students' academic rendition (Stanley, 2014).

Students having a high financial status gain public attention and peaceful surroundings that would improve their academic achievement (Chandra \& Azimuddin, 2003). Researchers demonstrate that financial status of the students correlates with academic achievement (Bhat, Joshi, \& Wani 2016). Parents' educational attainment and socioeconomic status or income is 
the factors why students show consistency to their academic achievement compared to others (Kumar, 2016). Parents and guardians play a very big role to the students who are doing well in school. Parents' socioeconomic status and students' finance affects students' academic achievement in performing well in school (Suleman, Aslam, Shakir, \& Nisa, 2012). The status of a student in the society sees the family income as a factor to consider regarding socioeconomic status (Okioga, 2013).

Higher family income may improve students' performance. Nevertheless, it is not an indicator for students who are from low-income families not to get serious and be responsible in performing school (Adzido, Dzogbede, Ahiave, Dorkpah, 2016). Socioeconomic status are divided into three major parts the high, middle, and low. Students found that those major parts influences their academic achievement and that adolescents with high and middle socioeconomic status have better academic achievement than in low socioeconomic status (Singh \& Choundhary, 2109). Consistency of finance in every day can help the students attain goals and be responsible on things that can help for their scholarly accomplishments (Saifi \& Mehmood, 2011). Students' socioeconomic status deals a big role in improving their academic performance. Parents' socioeconomic status is the factor of the students academically inclined and persistence (Abdu-Raheem, 2015). A study indicates that males having high socioeconomic status attain high academic achievement than on males having low socioeconomic status. This is due to their provided necessary facilities concerning their education, health, and comfort, which affect academic attainment (Ahamr \& Anmar, 2013).

The socioeconomic status is linked to academic achievement favorably yet weakly (White, 1982) Sexual orientation and financial status are the indicators of scholarly accomplishments of the students (Alade, Mwadingwe \& Victor, 2014). In addition, parental socioeconomic status directly affects the student's academic achievement (Sollano, Duhanylongsod, Aviso \& Moneva, 2018). Academic achievement of the senior secondary school student has a critical association to the high family financial status or high socioeconomic status of the family (Aliyu, 2016). Financial status as well as peer and student factors significantly predict the students' performance in school (Farooq, Chaundry, Shafiq \& Berhanu, 2011).

These articles are related and have a supporting data in order for the study to become strong and convincing. These anchor the content of the study, which are the school allowance and students' determination in studies.

\section{Research Methodology}

\subsection{Design}

The quantitative approach - descriptive survey was utilized by the researcher. It included the researcher process or the procedure and analysis of data gathered. It used in gathering data on the students' school allowance and students' determination in studies with the use of survey questionnaire.

\subsection{Environment}

The researcher conducted a study in Jagobiao National High School- Senior High. The Senior 


\section{Macrothink}

Business and Economic Research

ISSN 2162-4860

2020, Vol. 10, No. 1

High School Department offers more strand including Accountancy, Business and Management (ABM), Humanities and Social Sciences (HUMSS), General Academic Strand (GAS), Science, Technological, Engineering, and Mathematics (STEM), and Technical Vocational Livelihood (TVL).

\subsection{Respondents}

The researcher chose all the 250 students of Senior High School Department of Jagobiao National High School. The researcher went each room to ask the number of students every strand. Researcher asked from the strand including Accountancy, Business and Management (ABM), Humanities and Social Sciences (HUMSS), General Academic Strand (GAS), Science, Technological, Engineering, and Mathematics (STEM), and Technical Vocational Livelihood (TVL).

\subsection{Instrument}

The researcher produced two survey questionnaires. The first is checklist, the researcher asked the students about the range of school allowance that satisfy their needs in school from 0 to 61 and above. The second is Likert's scale, the researcher made it that consists of ten questions. The respondents answered the following questions with the rage from 1-3, that (1) is never, (2) sometimes, and (3) is always.

\subsection{Data Gathering Procedure}

First, the researcher submitted an approval letter to the head of the school to ask for an approval for the survey to conduct in Jagobiao National High School. Second, the researcher formulates survey questionnaires. Third, the researcher went to the classrooms and asked permission to the respondents to conduct the survey. Fourth, the researcher personally distributed the survey questionnaires to the respondents. The researcher waited and gave time to the respondents to answer the questions. Lastly, the researcher collected the data and analyzed the data gathered from the respondents.

\subsection{Statistical Treatment}

The researcher used weighted mean and chi-square in treating data and determining the association between the two variables especially the school allowance and students determination in studies.

\section{Presentation, Analysis and Interpretation of Data}

This chapter presents and show the data been gathered, it is also shows the analysis and interpretation of data. The purpose of this study was to identify if there is significant relationship between school allowance and students' determination in studies. 
Table 1. Students' School Allowance

\begin{tabular}{|l|l|l|l|}
\hline INDICATOR & AMOUNT & FREQUENCY & PERCENT (\%) \\
\hline \multirow{2}{*}{$\begin{array}{l}\text { Which of this range } \\
\text { of school allowance }\end{array}$} & $0-20$ pesos & 23 & $10 \%$ \\
\cline { 2 - 4 } $\begin{array}{l}\text { will satisfy your } \\
\text { daily needs? }\end{array}$ & $21-40$ pesos & 60 & $26.09 \%$ \\
\cline { 2 - 4 } & $41-60$ pesos & 77 & $33.48 \%$ \\
\cline { 2 - 4 } TOTAL & 61 pesos and above & 70 & $30.43 \%$ \\
\hline
\end{tabular}

$\mathrm{N}=230$

The table 1 above shows the frequency of the answered questions of the following indicator. The only indicator that asking for daily needs that satisfies the students answered by the respondents. There are 23 respondents answered the 0-20 pesos ( $\mathrm{P} 0.00-\mathrm{P} 20.00)$ school allowance and it is $10 \%$ of the total respondents. The number of respondents answered the $21-40$ pesos ( $\mathrm{P} 21.00-\mathrm{P} 40.00)$ school allowance are 60 respondents and it is $26.09 \%$ of the total respondents. There are 77 respondents answered the 41-60 pesos ( $\mathrm{P} 41.00$ - $\mathrm{P} 60.00)$ school allowance and it is $33.48 \%$ of the total respondents. Lastly, there are 70 respondents answered the 61 pesos and above (P61.00 and above) school allowance and it is $30.43 \%$ of the total respondents. In line with this study, students that are in low socioeconomic background are less academic achievement than students are of higher socioeconomic background (Suleman, Aslam, Hussain, Shakir, \& Nisa, 2012). In addition, strong family finances lead to increased encouragement, learning and thus better academic performance for students (Adzido, Ahiave \& Dzogbede, 2016). As a result, socioeconomic status affects academic performance of students significantly, because their socioeconomic status should not hinder students from achieving what they want to achieve (Sollano, Duhaylongsod, Aviso \& Moneva, 2018).

Table 2. Students' Determination in Studies

\begin{tabular}{|l|l|l|}
\hline INDICATOR/S & MEAN & INTERPRETATION \\
\hline I am eager to go to school everyday & 2.51 & SOMETIMES \\
\hline I always do my project & 2.56 & SOMETIMES \\
\hline I pass my project on time & 2.30 & SOMETIMES \\
\hline I participated in every class discussions & 2.31 & SOMETIMES \\
\hline I join extra-curricular activities & 2.15 & SOMETIMES \\
\hline I read books for extra knowledge & 2.15 & SOMETIMES \\
\hline I do my home works & 2.46 & SOMETIMES \\
\hline I do advance study & 1.98 & SOMETIMES \\
\hline I always take down notes & 2.50 & SOMETIMES \\
\hline I always join school program for additional points & 2.13 & SOMETIMES \\
\hline Overall Weighted Mean & 2.30 & SOMETIMES \\
\hline
\end{tabular}

N=230, LEGEND: Always (1.00-1.67), Sometimes (1.68-2.64), \& Never (2.65-3.00) 


\section{MlMacrothink}

Business and Economic Research ISSN 2162-4860 2020, Vol. 10, No. 1

The table 2 above shows that the 10 indicators had a three highest and lowest weighted mean that interpreted as sometimes. The first highest has a weighted mean of 2.56, the second highest has a weighted mean of 2.51, and the last highest has a weighted mean of 2.50 . The first lowest weighted mean is 1.98 , the second lowest weighted mean is 2.13 , and lastly the lowest weighted mean is 2.15 . While the overall weighted mean of the second variable interpreted as sometimes and has a weighted mean of 2.30. Teacher and school have to instill in students learning aspiration and encourage them to formulate clear and realistic goals for their future (Hardre, Sullivan \& Crowson, 2009). Besides, schools that do not have adequate facilities and service like prescribed textbooks often have poor academic performance (ALshamari, Saguban, Pasay-an, Altheban \& Al-Shamari, 2018). As a result, students are more interested in getting high scores as they find these result to be the greatest incentives and academic achievement that will adversely affect their ability to do well in the end (Gbollie \& Keamu, 2017).

Table 3. School Allowance and Students' Determination in Studies

\begin{tabular}{|l|l|l|l|}
\hline & Value & df & Asymp. Sig. (2-sided) \\
\hline Pearson Chi-Square & $46.369^{\mathrm{a}}$ & 42 & .297 \\
\hline Likelihood Ratio & 54.112 & 42 & .100 \\
\hline Linear-by-Linear Association & 2.832 & 1 & .092 \\
\hline N of Valid Cases & 230 & & \\
\hline
\end{tabular}

a. 43 cells $(71.7 \%)$ have expected count less than 5 . Te minimum expected count is .10.

The table shows that the $p$-value (.297) is greater than significant level $(\alpha=0.5)$. There is no significant association between school allowance of students and students' determination in studies. On the contrary, some researches show that great socioeconomic status is the best indicator for the success of students (Farooq, Chaundry, Shafiq \& Berhanu, 2011). In addition, parents' daily income is having a high and positive correlation regarding the students' academic performance (Abdu-Raheem, 2015). Lastly, the student whose home structure is high and medium has the high expectation that will have a better academic performance than students whose home structure is low (Singh \& Choundhary, 2019).

\section{Summary of Findings, Conclusion and Recommendation}

This chapter presents the summary, conclusions and recommendation of this study on school allowance and students' determination in studies of the Jagobiao National High School Senior High School Department.

\subsection{Findings}

The result of the study shows the association between school allowance and students' determination in studies. The highest range of school allowance of the students on the given choices is forty-one to sixty-one pesos, there are thirty three, and forty-eight percent students got this range of daily allowance. 
The students' determination in studies regardless of their daily allowance is very pertinent for their daily life. The result of the overall mean is been interpreted as sometimes. Most of the students are very eager to go to school always and always do their project or even to take down notes.

There was no positive association because students' determination in studies does not connect to the students' school allowances. Base on the findings whether the students' school allowances is high or low, there are students that their determination would not be changed. The quality of willingness in school is better than the quantity of school allowance they have.

\subsection{Conclusion}

The research study reveals that school allowances of the students are not related to the determination of the students towards their studies. Thus, students are likely having willingness in school even regardless of amount of their daily allowance. Students have determination in their studies. They go to school with eagerness. They produce projects. They do one work for advance study. In addition, school allowance or the socioeconomic status of the student is not a hindrance in attaining goals. Whether the school allowance of the student is high or low, the performance of the students is not affected.

\subsection{Recommendation}

The following are the recommendations of the researcher based on the gathered data:

1) Students must be responsible on their own for them to learn and have an output of their schooling.

Students need to focus their attention in attaining goals in life.

2) Conduct a program that targeting how to manage school allowance.

3) Teachers should have an assessment to their students every time there is a problem about them.

4) Parents should support their students to their school works, assignment, and project to boost their determination in school.

\section{Acknowledgement}

I would like to say thank you to our Almighty God for giving me enough knowledge and strength to face the obstacles doing this research study.

To our principal Ms. Juvy M. Sosas for providing a facilities and things to me and also to my co-students.

To my beloved adviser Mr. Richard F. Ruelan that is always there to give motivation on me to finish my study.

I would like to express my deepest gratitude to my parents to their encouragement, financial assistance as well as their full support to finish this research. 
And I take this opportunity to express my sincere thanks for all the people especially to my classmates for their unceasing encouragement, help, knowledge and equipment to finish this research wonderful.

\section{References}

Abdu-Raheem (2015). Parents' socioeconomic status as predictor of secondary school students' academic performance in ekitistate, Nigeria. Journal of Education and Practice, 6(1), 123-128. [Online] Available: https://files,eric,ed,gov/fulltext/EJIo83795.pdf

Adzido, R., Ahiave, E., \& Dzogbede, O. (2016). Assessment of family income on academic performance of tertiary students: the case of ho polytechnic, Ghana. International Journal of Academic Research in Accounting Finance and Management Sciences, 6(3), 154-169. https://doi.org/10.6007/IJARAFMS/v6-i3/2221

Ahmar, F., \& Anwar, E. (2013). Socioeconomic status and its relation to academic achievement of higher secondary school students. IOSR Journal of Humanities and Social Sciences (IOSJR-JHSS), 13(6), 13-20. https://doi.org/10.9790/0837-1361320

Alade, O., Nwadingwe, I., \& Victor, I. (2014). Socioeconomic status and gender as predictors of students' academic achievement in economics. Journal of Education and Practice, 5(9), 96-110. [Online] Available:

https://pdfs,semanticscholar,org/b415/162c403fcfo42aaec2863e64afb31c766.pdf

Aliyu, G. (2016). Influence of socioeconomic status on academic achievement of senior secondary students in nassarawa zonal education area of kano state, nigeria. Asian Journal of Educational Research, 4(4), 1-8. [Online] Available: www.multidisciplinaryjournals.com

Bhat, M., Josji, J., \& Wani, I. (2016). Effect of socioeconomic status on academic performance of secondary school students. The International Journal of Indian Psychology, 3(4), 33-37.

Chandra, R., \& Azimuddin, S. (2019). Influence of socioeconomic status on academic achievement of secondary school students of lucknow city. International Journal of Scientific \& Engineering Research, 4(12), 1951-1959.

El-Seoud, S. A., Eddin T., Seddiek N., El-Khouly, M., \& Nosseir, A. (2014). E-learning a motivation: a research study on the effect of e-learning on higher education. International Journal of Emerging Technologies in Learning, 9(4).

https://dx.doi.org/10.3991/ijet.v9i4.3465

Farooq, M., Chaudry, A., Shafiq, M., \& Berhanu, G. (2011). Factors affecting students quality of academic performance: a case of secondary school level. Journal of Quality and Technology Management, 7(2), 01-14.

Gbollie, C., \& Keamu, H. (2017). Students' academic performance: the role of motivation, strategies, perceived factors hindering Liberian junior and senior high school students learning. Educational Research International, 1-11. https://doi.org/10.1155/2017/1789084 


\section{Al Macrothink}

Business and Economic Research ISSN 2162-4860 2020, Vol. 10, No. 1

Hardre, P., Sullivan, D., \& Crowson, H. (2009) Students characteristics and motivation in rural high schools. Journal of Research in Rural Education, 24(16), 1-16. [Online] Available: https://jrre.psu.edu./articles/24-16.pdf

Hart, C. (2012). Factors associated with student persistence in an online program of study: a revies of the literature. Journal of Interactive Online Learning, 11(1), 1541-4914. [Online] Available: www.ncor.org/jiol

Jayanthi, V., Balakrishnan, S., Ching, A., Latiff, N., \& Nasirdeen, A. (2014) Factors contributing to academic performance of students in a tertiary institution in singapore. American Journal of Educational Research, 2(9), 752-758.

https://doi.org/10.12691/education-2-9-8

Kumar, N. (2016). Impact of parental socio economic factors on the performance of students in IIT-JEE. General Articles, 110(11), 2079-2081.

https://doi.org/10.18520/cs/v110/111/2079-2081

Li, L. (2012). A study of attitude, self-efficacy, effort and academic achievement of city u students towards research methods and statistics. Discovery - SS Student E - Journal, 1, 154-183.

Linvill, D. (2014). Student interest and engagement in the classroom: relationship with student personality and developmental variables. Southern Communication Journal, 79(3), 201-214. https://dx.doi.org/10.1080/1041794x.2014.884156

MeenuDev, D. (2016). Factors affecting the academic achievement: a study of elementary school students of NCR Delhi, India. Journal of Education and Practice, 7(4).

Okioga, C. (2013). The impact of students' socio economic background on academic performance in universities, a case of students in Kisii university college. American International Journal of Social Science, 2(2), 38-45.

Ryan, M., \& Deci, E. (2000). Self-determination theory and the facilitation of intrinsic motivation, social development, and well-being. American Psychologist, 55(1), 68-78. https://doi.org/10.1037/0003-066X.55.1.68

Rossi, M. (2017). Factors affecting academic performance of university evening students. Journal of Education and Human Development, 6(1), 96-102.

https://doi.org/10.15640/jehd.v6n1a10

Saeed, S., \& Zyngier, D. (2012). How motivations influence student engagement: a qualitative case study. Journal of Education and Learning, 1(2).

https://doi.org/10.5539/jel.v1n2p252

Saifi, S., \& Mehmood, T. (2011). Effects of socioeconomic status on students' achievement. International Journal of Social Sciences and Education, 1(2), 119-128. [Online] Available: https://www.ijsee.com/sites/default/files/issues/2011/uli2/p3/paper,pdf

Shahzadi, E., \& Ahmad, Z. (2011) A study on academic performance of university students. 
Proc. $80^{\text {th }}$ International Conference on Recent advances in Statistics, 255-258.

Singh, P., \& Choudhary, G. (2015). Impact of socioeconomic status on academic achievement of school students: an investigation. International Journal of Applied Research, 1(4), 266-272268.

Singh, S., \& Malik, S. (2016). Factors affecting academic performance of students. Parifex-Indian Journal of Research, 5(4), 176-178.

Sollano, A., Duhaylungsod, K., Aviso, M., \& Moneva, J. (2018) Daily allowance and academic performance. International Journal of Engineering Science and Computing, 8(6), 1968-1969.

Stanley, E. (2014). Discipline and academic performance (A study of selected secondary schools in Lagos, Nigeria). International Journal of Academic Research in Progressive Education and Development, 3(1). https://doi.org/10.6007/IJARPED/v3-i1/758

Suleman, Q., \& Hussain, I. (2014) Effects of classroom physical environment on the academic achievement scores of secondary school students in kohat division, Pakistan. International Journal of Learning and Development, 4(1).

https://doi.org/10.5296/ijld.v4i1.5174

White, K. (1982). The relation between socioeconomic status and academic achievement. Psychological Bulletin, 91(3), 461-481. https://doi.org/10.1037/0033-2909.91.3.461

\section{Glossary}

School allowance the following terminology is operationally defined to fully understand the study:

Students' determination in study is an attitude of a student that refers to the firmness in different things. It is also showing that students are already deciding to do something and they will not let anyone stop them.

School allowance is a daily finance of the students that can help them to sustain their needs in school.

Socioeconomic Status usually categorized into three levels the high, middle, and low and these describes the places a family or an individual may fall into. Socioeconomic status is also measures a person's job experience, income, and occupation. 


\section{Appendix}

Appendix 1. School Allowance

\begin{tabular}{|l|}
\hline 1$)$. Which of these range of school allowance will satisfy your daily needs? \\
\hline $0-20$ pesos \\
\hline $21-40$ pesos \\
\hline $41-60$ pesos \\
\hline 61 and above \\
\hline
\end{tabular}

Appendix 2. Students' Determination in Studies

Directions: Put check and rate your honesty base on what you actually do.

LEGEND: (3) always (2) sometimes (1) never

\begin{tabular}{|l|l|l|l|}
\hline & ALWAYS & SOMETIMES & NEVER \\
\hline 1) I am eager to go to school every day. & & & \\
\hline 2) I always do my project. & & & \\
\hline 3) I pass my project on time. & & & \\
\hline 4) I participated in every class discussions. & & & \\
\hline 5) I join extra-curricular activities & & & \\
\hline 6) I read books for extra knowledge & & & \\
\hline 7) I do my home works. & & & \\
\hline 8) I do advance study. & & & \\
\hline 9) I always take down notes. & & & \\
\hline $\begin{array}{l}\text { 10) I always join school program for additional } \\
\text { points. }\end{array}$ & & & \\
\hline
\end{tabular}

\section{Copyright Disclaimer}

Copyright for this article is retained by the author(s), with first publication rights granted to the journal.

This is an open-access article distributed under the terms and conditions of the Creative Commons Attribution license (http://creativecommons.org/licenses/by/4.0/). 